Ao que tudo indica, Diégues Júnior ainda não considera definitivo o trabalho em sua feição atual, de modo que, em edição futura, tratará, por certo, de precisar e completar os elementos informativos, bem como de aprofundar a interpretação dos fenômenos. Tomará em consideração, em escala maior, os estudos especializados dêstes últimos dez ou quinze anos. Neste sentido será útil que reveja, por exemplo, à luz das recentes contribuições sôbre a aculturação amerindia, as páginas relativas ao que os indios nos legaram, que insista mais nos aspectos característicos e nos valores determinantes do "ethos" brasileiro, que discuta e comente as pesquisas há pouco realizadas sôbre a situação racial nas diferentes regióes do País. Tudo isto evidentemente sem sacrificar o caráter popular do livro.

Como não há terminologia uniforme nem sequer entre os próprios antropólogos, o leitor comum sente, não raro, dificuldade em apreender o significado de têrmos técnicos, como aculturação, assimilação e integração de grupos alienígenas, raça e etnia, "ethos" cultural e tantos outros. E o autor parece empregar alguns dêles como sinônimos, o que tornaria aconselhável uma definição de seu conteúdo. Aliás, nunca sera demais acentuar, mesmo em obras de divulgação, o rigor metodológico indispensável às ciências humanas, principalmente por ser nelas mais difícil do que nas ciências naturais o enunciado e a colocação dos problemas, bem como o desenvolvimento dos trabalhos. Sugerimos também que em edição futura seja atualizada a bibliografia, a fim de que ela se torne fonte de informação segura para os que pretendam utilizá-la como ponto de partida para um estudo mais aprofundado do assunto.

Se fazemos essas observações, é porque desejamos ver o livro cada vez mais aperfeicoado. Trabalhos como Etnias e Culturas no Brasil podem contribuir para a correção ou eliminação de estereótipos populares de base emocional, indicar ao público o alcance teórico e prático das pesquisas antropológicas e - talvez - dar a entender a alguns dos governantes responsáveis pela imigração e povoamento que já é tempo de se passar do plano da rotina empírica para uma política orientada segundo os resultados da ciência.

\title{
Egon Schaden
}

IRMGARD LANG: Die Rassenverhälnisse Brasiliens. Eine soziologische und sozialgeschichtliche Studie. Inaugural-Dissertation zur Erlangung der Doktorwürde der Hohen Philosophischen Fakultät der Johannes-Gutenberg-Universität Mainz. 618 págs., (hectogr.). Mogúncia, 1955

Enquanto, nestes últimos anos, cientistas brasileiros e estrangeiros, como Florestan Fernandes, Thales de Azevedo, Charles Wagley, Roger Bastide, Anatol H. Rosenfeld e outros, através de inúmeras pesquisas de campo, têm procurado elucidar a situação racial do Brasil, especialmente com referência ao negro, o Professor W. E. Mühlmann, eminente antropólogo da Universidade de Mogúncia, sugeriu o mesmo tema como objeto de uma dissertação puramente teórica, desligada da observação direta.

O trabalho, apesar de o título sugerir estudo mais amplo, se limita à situação do negro no Brasil. Irmgard Lang aborda o problema, do àngulo de uma sociologia empírica, em duas partes principais: na primeira, analisa a situação atual dos negros e mulatos na sociedade brasileira, examinando as categorias sócio-raciais, as relações raciais, as possibilidades 
de ascensão dos homens de côr, a discriminação tal como se reflete na lei, e a reação dos homens de côr. Na segunda parte, investiga as diversas culturas do Brasil, separadamente e em sua interrelação, focalizando especialmente o problema do negro, seu lugar na estrutura social do Brasil e da África, e a perda da tradição africana. Uma introdução histórica relativa às condições vigentes em Portugal e às linhas mestras da formação do Brasil, bem como um resumo das conclusões da pesquisa completam a obra.

O resultado a que a autora chega após a investigação de tantos tópicos parciais consiste na tentativa de esclarecer, mais de perto, com referència à questão do negro, a fórmula: "Não há preconceito de côr no Brasil". A respeito disso, lemos: "As atuais relações interraciais apresentamse de forma muito complexa e podem ser entendidas somente após a elucidação dos dados intencionais que constituem o pano de fundo" (pág. $500)$; "elas são determinadas pela ambivalência das atitudes de ambos os lados, sendo que a idéia diretriz de uma democracia racial sem preconceitos, apoiada por medidas legais, produz uma atmosfera suportável para as duas partes. Há indícios de tensões mais fortes; mas o clima social não nos faz prever uma acentuação das tensões, como conseqüência de uma cismogênese simétrica e como única possibilidade de desenvolvimento. Não se pode dizer, por ora, até que ponto se concretizará a opinião de que o Brasil virá a constituir um povo homogêneo, com o moreno como tipo dominante; todavia, tal evolução de modo algum se afigura mera utopia. Um Brasil moreno dêsse tipo teria solucionado, da maneira mais favorável, o seu problema racial” (pág. 523).

Tais conclusões certamente não têm o valor de surpreendente novidade. No entanto, obtido pelo recurso às numerosas obras relativas à mesma temática, o resultado reflete, em linhas gerais, o estado atual do problema. Se é verdade que a Antropologia não se vê enriquecida substancialmente por novos conhecimentos, por outro lado não foi esta a pretensão da autora.

$\mathrm{E}^{\prime}$ indiscutível, porém, o valor funcional da obra para o leitor alemão. A riqueza do material exposto representa uma boa fonte de informações; a interpretação, segundo tópicos gerais e bem organizados, é sugestiva para o antropólogo. Realmente, em língua alemã e no âmbito da cultura alemã, nunca se escreveu sôbre êsses problemas com igual conhecimento de causa.

Ao comentarista interessado nas qualidades da autora impressiona, antes do mais, o tipo de luta que ela trava com a complexa tarefa de reduzir a prposições válidas situações de um mundo situado aquém do horizonte europeu. Nisso, Irmgard Lang revela inteligência e personalidade científica. O momento de inteligência exigido em primeiro lugar por trabalhos dêsse tipo é a "sagacidade" (ultrapassando o sentido que the dá Kant), como capacidade de localizar as fontes. Numa busca incansável, a autora conseguiu obter documentos essenciais da literatura cientifica e geral, tanto na Alemanha como em Portugal; ademais, soube aproveitar de forma ampla os seus contactos transoceânicos com cientistas residentes no Brasil. A cada elemento obtido nessa caça transformouo, com meticulosidade conscienciosa, em tijôlo do edifício científico, e disso dão testemunho quase 100 páginas de notas bibliográficas. Ainda assim, não se perdeu a coerência e a unidade da exposição.

No entanto, o que se afigura problemático é a circunstância de a tarefa ter sido empreendida como "arm-chair work". Apesar de tôda a ca- 
pacidade de superar a falta de contacto direto com a realidade brasileira, a autora não logrou eliminar tôdas as desvantagens de tal posição. Por mais que se esforçasse, não teve acesso a uma parte da literatura, e as obras utilizadas nem sempre o são com as necessárias restrições críticas. $\mathrm{E}^{\prime}$ quase inevitável que isso ocorra em trabalho realizado longe do campo. Em etnias estranhas, as fontes bibliográficas se revestem de significado diverso do que lhe é atribuído na própria etnia e a apreciação adequada só pode decorrer do trato imediato. Ademais, a falta de contacto com a realidade em aprêço não raro tem efeito negativo na interpretação do material, já que o intérprete não tem, para orientá-lo, a visão da configuração total da cultura estranha. Todos êsses momentos evidentemente induzem a deformações. Nota-se, por exemplo, uma injustificada supervalorização de autores como Oliveira Vianna e Gilberto Freyre. Estereótipos como "mazombo" pertencem à história e já não desempenham nenhum papel na realidade lingüística. Na formulação de leis gerais, em que pese tôda a cautela, a autora não leva na devida conta as peculiaridades regionais. Não reconheceu, na medida necessária, a verdade da frase de Lourenço Filho, citada a certa altura, de que não há um Brasil e sim muitos Brasis. Nuito problemáticas - e só explicáveis pela falta de contacto com a realidade brasileira - são as idéias de um futuro Brasil moreno, cuja possibilidade não é considerada como mera utopia. Tal concepção - relíquia do pensamento de Martius - não tem sequer base genética.

A questão que se levanta em face de tais reflexões é, de forma geral, a seguinte: até que ponto se podem aceitar, nos dias que correm, estados empírico-sociológicos como mero trabalho de gabinete? O orientador da tese, que neste caso é atingido pela crítica em face das conseqüências quase inevitáveis de tal tipo de trabalho, poderia apresentar um argumento prático, o de que diante da deficiência dos conhecimentos no âmbito de um pais é preferível realizar algo com recursos insuficientes, a não fazer nada. Afinal, o trabalho de gabinete não pode ser posto em dúvilla como possibilidade. A visão do campo à distância permite, por vêzes, uma apreensão mais fiel do objeto do que a visão de dentro do próprio campo. Aliás, a realização de Irmgard Lang não constitui uma prova contra esse método de trabalho. Por outro lado, a justificação tem seu lado problemático numa época de tão intensas comunicações pelo globo terrestre, salvo se nos referimos a casos excepcionais (como a descrição das pontes de Londres, por Kant, ou a caracteriíação de países estranhos, por Wappäus).

A autora merece que se confie em suas futuras realizaçoes. Cumpriria oferecer-the oportunidade para realizar pesquisas de campo no Brasil, a fim de que possa eliminar as deficiencias de seu trabalho.

\section{E. A. von Buggenhagen}

FRIEDRICH SCHNEIDER: Triebkräfte der Pädagogik der Völker. Eine Einführung in die vergleichende Erziehungswissenschaft. 503 págs. Otto Müller Verlag. Salzburgo, 1947.

O objetivo da Pedagogia Comparada é, em primeiro lugar, responder a questões pedagógicas especiais (idiográficas) pela comparação de fenômenos de ordem cultural geral ou pròpriamente pedagógica, do pre- 